\title{
Pemberantasan Kejahatan Ekonomi antar Negara dengan Perjanjian Ekstradisi (Perspektif Indonesia)
}

\author{
Mohd. Burhan Tsani
}

\begin{abstract}
The recent case of Edy Tansil and Hendra Rahardja is one of small examples of how the development of white colour crime has become trans-national. Thus, Indonesia should be actively involving itself among other countries to provide a settlement of the criminals. Several other countries have an extradition agreement with Indonesia, while others do not. The extradition itself boasts a different view from one country using common law systems to one employing civil law systems whether or not the extradition would be allowed, if the treaty were not yet proved. This article endeavours the forms of white colour criminals, and what contribution of the extradition agreement in precluding the criminals among countries.
\end{abstract}

\section{Pendahuluan}

Dewasa ini bangsa Indonesia masih terus dituntut untuk mampu mengatasi krisis ekonomi. Permasalahan kejahatan ekonomi masih marak dan cukup serius. Di Indonesia tercatat ada 1.400 orang termuat dalam daftar orang tercela bagi dunia perbankan. ${ }^{1}$ Banyak modal hasil kejahatan perbankan di Indonesia dilarikan dan diendapkan di luar negeri seperti
Singapura dan Hongkong. Karena kejahatan ekonomi' memiliki modus operandi yang memanfaatkan jaringan transaksi dunia, para pelaku kejahatan dapat dengan leluasa menimbun hasil kejahatan mereka dengan aman di negara-negara yang sulit dijangkau oleh hukum Indonesia. ${ }^{2}$

'Harian Suara Pembaharuan. Tanggal 19 April 1999.

Harian Suara Pembaharuan. Tanggal eo April 1999. 
Pada akhir tahun 1998 mencuat masalah keberadaan Edy Tansil di Cina. Edy Tanșil, yang telah merugikan Indonesia senilai 1,3 triliun, memang ramai diberitakan telah melarikan diri ke luar negen. ' Sampai saat ini keberadaan Edy Tansil yang benar belum, terungkap. Perwakilan Republik Indonesia untuk Cina, sudah bekerja sama dengan Cina, dalam usaha mengusut kebenaran berita mengenai keberadaan Edy Tansil di Cina. ${ }^{3}$ Kemungkinan ekstradiși Edy Tansil ke Indonesia cukup sulit untuk menjadi kenyataan.

Pada tanggal 16 Juni 1999 proses pengadilan terhadap Hendra Rahardja di Cen-. tral Local Court Sydney; Australia sudah dimulai. Hendra Rahardja (mantan Komisaris Bank Harapan Santosa) sudah melakukan berbagai kejahatan ekonomi, antara lain dengan memberikan pinjaman melampaui batas, sebesar Rp.700 miliar, kepada enam perusahaan keluarganya. Pemerintah Indonesia sudah melakukan langkah-langkah konkrit, bekerja sama dengan INTERPOL maupun Kejaksaan Agung Australia, untuk , berusaha mengekstradisikan Hendra Rahardja ke Indonesia. ${ }^{4}$ Sampai saat ini harapan ekstradisi Hendra Rahardja masih belum menentu.

Kasus-kasus tersebut mérupakan sebagian kecil contoh perkembangan kejahatan ekonomi yang sudah menjadi transnasional (antar negara), dan melibatkan lebih dari seorang pelaku kejahatan. Antara
Indonesia dan negara-negara yang perlu dilibatkan dalam penyelesaian. kejahatan ekonomi tersebut, ada yang sudah memiliki perjänjian ekstradisi dan ada yang belum memilikinya. Bertolak pada fenomena ini dapat dipertanyakan peran apa yang dapat disumbangkan oleh perjanjian ekstradisi dalam memberantas kejahatan ekonomi antar negara

\section{Kejahatan Ekonomi antar Negara}

Dalam penulisan ini yang dimaksud dengan kejahatan ekonomi antar negara adalah kejahatan ekonomi yang' unsur-unsur kejahatannya tidak hanya berada di satu negara. Kejahatan ekonomi meliputi antara lain: ${ }^{5}$

1. penyelundupan (smuggling);

2. kejahatan di bidang perbankan 'banking crime);

3. kejahatan di bidang perniagaan (commercial crime);

4. kejahatan komputer (computer crime);

5. kejahatan yang berkenaan dengan hukum lingkungan;

6. kejahatan di bidang HaKI (hak'atas kekayaan intelektual);

7. kecurangan di bidang kepabeanan (custom fraude).

Kecurangan di bidang kepabeanan, dapat terdiri dari pelanggaran-pelanggaran dalam hal: ${ }^{6}$

${ }^{3}$ Harian Republika. Tanggal 31 Desember 1998. Harian Suara Pëmbaruan. Tànggal 2 Januari 1999.

${ }^{4}$ Harian Suara Pembaruan. Tanggal 9 Maret 1999. Tanggal 4 Juni 1999. Harian Republika. Tanggal 11,12 Juni 1999.

5Hamzah. Course - Materials Penataran Nasional Hukum Pidana, dan Kriminologi. di Universitas Diponegoro: Sematang, 23-31. Nopember $1998 \mathrm{HIm}$. 2, 3.

${ }^{6} /$ bid. 
1. pengangkut tidak memenuhi ketentuan: "barang' impor harus di bawa ke kantor Pabean tujuan pertama melalui jalur yang ditetapkan dan kedatangan tersebut wajib diberitahukan oleh penganǵkutnya";

2. pengángkut yang telah memenuhi ketentuan Pasal 7 ayat (3) UndangUndang Kepabeanan, 1995, tetapi jumlah barang yang dibongkar kurang dari yang diberitahukan dalam pemberitahuan pabean dan tidak dapat membuktikan bahwa kesalahan tersebut terjadi di luar kemämpuannya;

3. pengangkut telah memenuhi ketentuan Pasal 7 ayat (1), barang impor telah di bawa ke kantor pabean dan ayàt (2) dalam keadaan darurat membongkar barang. impor terlebih dahulu kemudian melapor ke kantor pabean terdekat, tetapi jumlah barang yang dibongkar lebih banyak dari pada yang diberitahukan dalam pemberitahuan pabean;

4. mengeluarkan barang dari Kawasan Pabean sebelum diberikan persetujuan oleh Pejabat Bea Cukai;

5. eksportir yang tidak melaporkan pembatalan èspornya;

6. pengangkut tidak memberitahukan barang yang diangkut meninggalkan Kantor Pabean dengan tujuan keluar 'daerah Päbean atau pengangkutan barang dari satu tempat ke tempat lain dalam daerah Pabean;

7. pengangkut yang telah memenuhi ketentuan tentang pengangkutan barang dari satu tempat ke tempat lain dengan pemberitahuan Pabean, tetapi barang yang diangkut tidak sampai ke tempat tujuan atau jumlah barang setelah sampai di tempat tujuan tidak sesuai dengan
Pemberitahuan Pabean dan tidak dapat membuktikan bahwa kesalahan tersebut terjadi di luar kemampuannnya;

8. "mengeluarkan barang dari tempat penimbunan berikat sebelum diberikan persetujuan oleh pejabat Bea dan Cukai;

9. pengangkut atau pengusaha tidak memberikan bantuan yang layak jika tidak tersedia akomodasi di sarana pengangkut atau tempat lain;

10. orang tidak memenuhi permintaan pejabat Bea dan Cukai agar importir; eksportir, $\because$ pengangkut, pengusaha tempat penimbunan sementara, pengusaha di tempat penimbunan berikat atau yang mewakilinya menyerahkan barang untuk - diperiksa, membuka sarana pengangkutan, atäu bagiannya, dan membuka setiap bungkusan atau pengemas untuk diperiksa;

11. orang salah memberitahukan jenis dan atau jumlah barang dalam pemberitahuan pabean atas ekspor; :

12. importir, eksportir, pengusaha tempat penimbunan sementara, pengusaha tempat penimbùnan berikat, pengusaha pengurusan jasa kepabeanan atau "pengusahà pengangkutan, tidak memenuhi permintaan pejabat Bea dan Cukai untuk menyerahkan buku, catatan, surat menyurat yang bertalian dengan impor atau ekspor, atau tidak bersedia untuk diperiksa kesediaan barangnya;

13. orang yang menyebabkan Pejabat Bea dan Cukai tidak dapat melaksanakan wewenangnya untuk memeriksa bangunan dan tempat lain atau tidak dapat memasuki dan memeriksă bängunan dan tempat yang bukan rumah tinggal;

14. orang yang tidak melaksanakan perintah penghentian pembongkaran dari sarana 
pengangkut apabila ternyata barang yang dibongkar tersebut bertentangan dengan ketentuan yang berlaku;

15. pengangkut menolak untuk memenuhi permintaan Pejabat Bea dan Cukai untuk menghentikan sarana pengangkutnya, sarana pengangkut di bawa ke kantor Pabean atau tempat lain yang sesuai untuk keperluan pemeriksaan atas biaya yang bersalah dan / atau menunjukkan semua dokumen pengangkutan serta pemberitahuan Pabean yang diwajibkan menurut Undang-Undang Kepabeanan.

Berikut adalah contoh skenario terjadinya kecurangan antar negara di bidang kepabeanan, yang mungkin ada kaitannya dengan masalah ekstradisi. Kecurangan dilakukan oleh seorang atau lebih warga negara Indonesia. Sebelum dilakukan proses hukum atau ketika sedang dilakukan proses hukum si pelaku kejahatan berhasil melarikan diri atau bersembunyi di negara asing, misalnya ke negara tetangga.

Kecurangan dilakukan oleh warga negara. asing. Kemudian dia berhasil meloloskan diri pulang ke negaranya (negara tempat dia mempunyai kewarganegaraan), atau dia melarikan dir ke negara ketiga (negara manapun, selain negara.tempat dia berkewarganegaraan).

Penyelundupan fisik yaitu memasukkan atau mengheluarkan barang ke / dari suatu negara tanpa dokumen. Penyelundupan administratif, yaitu ada dokumen, tetapi tidak sesuai dengan jumlah atau jenis atau harga barang yang tersebut di dalamnya. Kejahatan yang erat dengan penyelundupan yaitu penadahan hasil penyelundupan. ${ }^{7}$

Penyelundupan antar negara dapat terjadi apabila pelaku penyelundupan adalah warga negara asing. Kemudian dia berhasil meloloskan diri pulang ke negaranya atau menyelamatkan diri di negara ketiga. Penyelundupan dilakukan oleh warga negara Indonesia. Kemudian dia berhasil melarikan diri dan bersembunyi di luar negeri: Kejahatan di bidang perbankan meliputi semua kejahatan yang berkaitan dengan dunia perbankan, bahkan termasuk pemalsuan uang dan pemalsuan sertifikat tanah untuk memperoleh agunan, credit card dan lain-lain. Sudah pasti dalam kejahatan ini termasuk kejahatan yang tercantum dalam UndangUndang Perbankan. Ada tiga kelompok kejahatan di bidang perbankan, yaitu: ${ }^{8}$

1. kejahatan di bidang perjanjian, legalitas bank atau melakukan aktivitas bank tanpa ijin;

2. kejahatan pemalsuan dokumen untuk memperoleh kredit;

3. pemalsuan yang menyangkut lalulintas giral.

Dalam kaitannya dengan masalah ekstradisi, kejahatan ini dapat dilakukan oleh warga negara Indonesia, atau warga negara asing. Selanjutnya pelaku kejahatan dapat lolos melarikan diri ke luar negeri. Dapat juga terjadi pelaku kejahatan yang warga negara asing itu masih tetap di negaranya sendiri.

\section{Tlbid.}

8/bid. 
Kejahatan komersial dapat berupa penipuan, terutama dalam ekspor dan impor. Misalnya barang yang dipesan sudah dibayar melalui $L / C$, namun barang yang dikirim, diangkut ke negara lain. Kejahatan dapat juga terjadi dengan mengirim barang yang sudah rusak (busuk), atau ada penipuan mengenai mutu barang. Kadang-kadang kejahatan dilakukan dengan menenggelamkan kapal yang membawa barang untuk memperoleh assuransi. ${ }^{9}$

Berkenaan dengan ekstradisi, kejahatan komersial antar negara dapat terjadi apabila dilakukan oleh warga negara asing. Sebelum dilaksanakan proses pengadilan atau selama berlangsung proses peradilan, orang tersebut melarikan diri, bersembunyi di negara tempat dia punya kewarganegaraan, atau ke negara. ketiga. Apabila pelakunya warga negara sendiri, dapat juga terjadi yaitu ketika dia berhasil melarikan diri ke negara asing. Kejahatan yang berkaitan dengan komputer nerupakan bentuk kejahatan yang relatif baru. Untuk memberikan batasannya, ada tiga pendekatan (approach) yang dilakukan oleh negara-negara Eropa, yaitu:
a. forgery approach;
b. information approach;
c. property approach.

Menurut forgery approach, kejahatan komputer merupakan pemalsuan. Berdasarkan property approach, kejahatan komputer merupakan kejahatan yang berkaitan dengan kekayaan. Menurut information approach kejahatan komputer merupakan kejahatan di bidang informasi. ${ }^{10}$ Kejahatan komputer sangat berpeluang menjadi kejahatan antar negara. Dalam kaitannya dengan ekstradisi, pelakunya adalah warga negara sendiri atau warga negara asing. Sangat dimungkinkan pelaku asing itu masih tetap berada di negaranya sendiri.

Dalam kejahatan terhadap hukum lingkungan ada dua jenis pengaturan hukum lingkungan. Pertama adalah penciptaan kaidah untuk mengatur tingkah laku masyarakat. Kedua menciptakan peraturan bagi aparat pemerintah untuk mengatur lingkungan." Kejahatan lingkungan dapat dilakukan oleh masyarakat dan aparat pemerintah. Terjadi kejahatan antar negara apabila pelaku ini lari atau mencari perlindungan di negara asing. Dalam hal ini masyarakat dapat juga berupa individu asing. Ada kemungkinan individu ini dapat lolos dan melarikan diri ke negaranya atau negara ketiga. Kejahatan hak atas kekayaan intelektual dapat dilakukan oleh warga negara sendiri atau warga negara asing. Kemungkinan lebih banyak dilakukan oleh warga negara asing. Perlu dingat bahwa dapat terjadi warga negara asing itu masih tetap berada di negaranya sendiri. Kejahatan hak atas kekayaan intelektual misalnya dilakukan dengan pembajakan hak cipta, pemalsuan merek, penggunaan secara illegal penemuanpenemuan yang sudah dipatenkan.

Mengingat cukup banyak kejahatan ekonomi dilakukan oleh koporasi, maka perlu juga disinggung apa yang dimaksud dengan kejahatan korporasi. Kejahatan korporasi

\footnotetext{
\%bid.

${ }^{10} / \mathrm{bid}$.

$11 / b i d$.
} 
adalah kegiatan ekonomi atau yang berkaitan dengan dunia bisnis, yang menimbulkan keresahan luas dalam masyarakat, yang menimbulkan kerugian material dan immaterial yang besar atau membahayakan masyarakat. Kejahatan korporasi biasanya dilakukan secara rahasia, sukar diketahui dan seringkali para korban pun tidak mengetahui kerugian yang dialaminya. ${ }^{12}$ Perilaku korporasi yang bersifat illegal seperti:

1. produk yang membahayakan kesehatan dan keselamatan jiwa manusia;

2. manipulasi pajak;

3. persaingan curang;

4. pencemaran;

5. penyuapan.

Ujud kerugian akibat kejahatan korporasi antara lain: ${ }^{13}$

1. ekonomi;

2. kesehàtan dan jiwa;

3. kerugian di bidang sosial dan moral.

Sudah pasti kejahatan korporasi dapat dilakukan oleh korporasi nasional atau korporasi asing.

\section{Perjanjian Ekstradisi}

Perjanjian ekstradisi adalah perjanjian internasional mengenai ekstradisi. Perjanjian internasional merupakan suatu persetujuan internasional yang ditandatangani antar negara dalam bentuk tertulis dan diatur oleh hukum internasional, apakah dibuat dalam wujud satu instrumen tunggal atau dalam dua instrumen atau lebih, yang saling berhubungan dan apapun yang menjadi penandáan khususnya. ${ }^{14}$ Dalam kaitannya dengan diakuinya organisasi internasional sebagai subjek hukum internasional, perjanjian internasional diartikan sebagai persetujuan internasional, yang diatur dengan hukum internasional, dan ditandatangani dalam bentuk tertulis: a) antar satu negara atau lebih dan satu organisasi internasional atau lebih atau; b) antar organisasi internasional.

Apakah persetujuan tersebut dituangkan dalam satu instrumen tunggal atau dalam dua instrumen atau lebih, yang saling berhubungan, dan apapun yang menjadi penandaan khususnya. ${ }^{15}$ Ekstradisi dapat didefinisikan menurut hukum nasional dan hukum intemasional. Definisi menurut hukum nasional, diambil sebagai contoh hukum nasional indonesia, yang memberi definisi ekstradisi sebagai penyerahan oleh suatu negara kepada negara yang meminta penyerahan seseorang yang disangka atau dipidana karena melakukan sesuatu kejahatan di luar wilayah negara yang menyerahkan dan di dalam yurisdiksi wilayah negara yang meminta penyerahan tersebut, karena berwenang untuk mengadili dan memidananya. ${ }^{16}$ Dalam hukum internasional ekstradisi dapat diberi definisi sebagai berikut:"

${ }^{12}$ Reksodiputro, Mardjono. "Tindak Pidana Korporasi dan Pertanggungjawabannya." Pidato Diẹs Natalis Ke. 47. PTIK Mabes Polri, Jakarta 1993. HIm. 8, 9.

${ }^{13}$ Susanto. Course - Materials Periataran Nasional Hukum Pidana dan Kriminologi. di Universitas Diponegoro. Semarang, 23-31 Nopember 1998. HIm. 18,19,22.

${ }^{14}$ Pasal 2 ayat (1) huruf a Konvensi Wina 1969.

${ }^{15}$ Pasal 2 ayat (1) huruf a Konvensi Wina 1969.

${ }^{16}$ Pasal 1 UU No. 1 Tahun 1979 tentang Ekstradisi

${ }^{17}$ Rudolf L Bindschedler. et.al. 1985. Encyclopedia of Public International Law. Vol. 8. . Hlm. 222. 
"Extradition designates the official surrender of a fugitive from justice, regardless of his consent, by the authorities of the state of residence to the authorities of another state for the purpose of criminal prosecution or the execution of a sentence."

Versi lain definisiekstradisi adalah sebagai berikut: ${ }^{18}$

"The term axtradition denotes the process whereby under treaty or upon a basis of reciprocity one state surrenders to another state at its request a person accused or convicted of a criminal offence committed against the laws of the requesting state, such requesting state, being competent to try the alleged offender:

Perjanjian ekstradisi dapat dituangkan dalam suatu perjanjian internasional bilateral ataupun multilateral. Bagi negara-negara yang sudah berhasil mencapai kesepakatan membuat suatu perjanjian ekstradisi, mereka berkewajiban untuk mentaati, menghormati dan melaksanakan perjanjian ekstradisi yang bersangkutan. Kadang-kadang pengaturan mengenai ekstradisi dituangkan dalam suatu perjanjian yang lebih komprehensif mengenal bantuan hukum antar negara di bidang kejahatan pada umumnya atau bahkan di bidang bantuan hukum dalam arti luas.

Pengaturan tentang ekștradisi terdiri dari perjanjian-perjanjian bilateral maupun multilateral dan undang-undang nasional. Substansi pengaturan ekstradisi dalam perjanjian internasional atau undang-undang nasional adalah uniform. Kesatuan dan paling tidak kesamaan ini dikarenakan secara timbal balik antar mereka saling mempengaruhi. Perjanjian yang lebih tua atau perjanjianperjanjian multilateral dipakai sebagai model perjanjian yang berikuțya. Sedang perjanjianperjanjian internasional dirancang dengan memperhatikan undang-undang nasional yang sudah ada mengenai ekstradisi.

Perjanjian internasional multilateral hanya untuk kawasan atau sub kawasan misalnya Eropa, Afrika, dan Amerika. Perjanjian multilateral ini hanya mencerminkan standar minimum hukuman bersama, tidak mengatur rincian yang diperlukan. Sedang perjanjian bilateral lebih fleksibel. ${ }^{19}$

Ekstradisi merupakan aspek yang paling penting dalam hal bantuan hukum antar negara di bidang kejahatan. Berbeda dengan pengusiran atau deportasi, motivasi pengembalian tersangka atau terpidana bukan untuk memelihara ketertiban umum atau keamanan domestik, tetapi untuk pelaksanaan pengadilan pidana di negara asing. Ekstradisi dimaksudkan untuk menjamin agar pelaku kejahatan berat tidak dapat menghindarkan diri dari tuntutan atau pemidanaan. ${ }^{20}$

Hukum internasional tidak membebani kewajiban kepada negara untuk mengekstradisikan kejahatan biasa dan juga tidak ada kewajiban untuk mengadili atau menghukum tersangka apabila ekstradisi gagal: Kewajiban untuk mengekstradisikan dapat terjadi bila didasarkan pada suatu perjanjian internasional. Hukum internasional juga tidak memuat pembatasan-pembatasan

${ }^{18}$ Starke.1989. Introduction to International Law. London: Butterworths. HIm. 352.

${ }^{19}$ Rudolf L Bindschedler. et.al. Op. Cit. HIm. 229-231.

${ }^{20} /$ bid. 
terhadap kebebasan suatu negara untuk mengekstradisikan. Di Juar pembatasan tersebut, apakah ekstradisi dipekenankan atau tidak apabila tidak ada satu perjanjian internasional, semata-mata ditentukan olẹ hukum nasional. Menurut negara-negara common law, ekstradisi tidak diperkenankan apabila tidak ada perjanjian internasional, sedangkan kebanyakan negara-negara civil law memperkenankan ekstradisi dengan tanpa adanya perjanjian internasional; atas dasar resiprositas dan undang-undang nasional mereka. ${ }^{21}$ Pada prinsipnya ekstradisi dilaksanakan terutama atas dasar perjanjian internasional bilateral atau regional tentang ekstradisi. Kalau tidak ada perjanjian internasional dapat dilakukan atas dasar resiprositas atau komitas. ${ }^{22}$ Mengenai Kejahatan yang dapat diekstradisikan, perjanjianperjanjian internasional yang lama atau undangundang nasional yang lama, menentukan bahwa kejahatan-kejahatan yang dapat diekstradisikan adalah kejahatan yang tercantum pada suatu daftar dalam. perjanjian internasional. Cara demikian dikenal sebagai metode penyebutan. Metode ini kurang baik untuk menghadapi perbedaan-perbedaan terminologi dalam berbagai kitab undangundang hukum pidana dan perkembangan tipe-tipe baru kejahatan. Kalau kejahatan baru ingin dimasukkan dalam daftar, perlu dibuat suatu perjanjian internasional pelengkap.

Perjanjian internasional dan undangundang ekstradisi yang lebih baru mendefinisikan kejahatan-kejahatan yang dapat diekstradisikan hanya sederhana dengan. referensi pada hukumannya. Cara demikian menganut metode eliminasi. Beberapa perjanjian mengkombinasikan kedua metode tersebut, yang menghasilkan daftar yang selalu terbuka. Beberapa perjanjian dan undang-undang yang tidak menggunakan daftar, menetapkan bahwa apabila satu dari beberapa kejahatan, merupakan suatu kejahatan yang dapat diekstradisikan, ekstradisi dapat diberikan untuk semua kejahatan. Cara ini dikenal sebagai ekstradisi assesor.

Ada sejumlah perjanjian internasional yang memerangi jenis kejahatan internasional tertentu. Kejahatan-kejahatan yang termuat dalam perjanjian-perjanjian internasional tersebut dianggap dimasukkan ke dalam perjanjian ekśstradisi yang ada. Ada beberápa syarat agar suatu kejahatan dapat diekstradisikan. Menurut aturan kriminalitas rangkap, kejahatan yang dapat diekstradisikan adalah perbuatan yang oleh kedua hukum negara yang meminta ekstradisi dan negara yang diminta merupakan kejahatan. Tidak satupun negara wajib, mengekstradisikan seseorang, karena melakukan perbuatan yang tidak diakui sebagai kejahatan oleh standar negara itu sendiri.

Agar suatu kejahatan dapat diekstradisikan ada yang mempersyaratkan bukti kesalahan. Pengadilan di negara common law mempersyaratkan bahwa negara peminta ekstradisi membuat bukti kesalahan buronan yang dimintakan ekstradisi. Bukti kesalahan ini tidak dipersyaratkan bagi buronan terpidana. Kebanyakan negara civil law menolak persyaratan tersebut. Verifikasi permintaan ekstradisi kurang lebih merupakan syarat formal. Dokumen penunjang harus melampirkan:

21/bid. HIm. 223.

22Mohd. Burhan Tsani. 1990. Hukum dan Hubungan Internasional. Yogyakarta: Liberty. HIm. 57. 
1. salinan perintah penahanan atau keputusan;

2. karakterisasi hukum mengenai kejahatan;

3. informasi mengenai identitas pelaku kejahatan

4. ringkasan mengenai fakta-fakta yang relevan.

Negara-negara civil law meminta bukti tambahan, termasuk bukti kesalahan, apabila ada keraguan yang beralasan apakah orang yang dimintakan ekstradisi benar-benar melakukan kejahatan, atau apabila ada kecurigaan yang beralasan bahwa kejahatan yang dapat dikembalikan yang ditundukkan kepada buronan tidak murni (asli).

Secara tradisional resiprositas mendasari keseluruhan struktur ekstradisi. Kalau tidak ada perjanjian internasional resiprositas dapat dipakai sebagai dasar. Penyerahan dapat dilakukan hanya sesudah negara peminta - secara tegas-tegas meyakinkan resiprositas tadi. Sekarang ini dalam praktik resiprositas lebih merupakan pepatah politik dibandingkan sebagai prasyarat hukum. Beberapa perjanjian dan undang-undang baru tidak mencantumkan resiprositas,

Menurut aturan spesialitas, yang merupakan aturan hukum internasional umum, seorang buronan tidak boleh ditahan, diadili atau dihukum di negara peminta ekstradisi atas dasar kejahatan apapun yang dilakukan sebelum penyerahannya. Dia hanya dapat ditahan, diadili atau dihukum atas kejahatan yang sebagai dasar pengabulan ekstradisi. Untuk kejahatan yang lain dapat diadili atau dihukum apabila dia tidak meninggalkan wilayah negara peminta dalam batas waktu tertentu, yaitu 30 atau 45 hari, sesudah bebas atau secara suka rela kembali atau secara sah diekstradisikan kembali ke negara peminta . tadi oleh negara ketiga atau negara yang menyerahkan dia menyetujuinya.

Sejumlah pengecualian terhadap kewajiban untuk mengekstradisikan dijumpai dalam hampir semua perjanjian ekstradisi atau undang-undang ekstradisi nasional. Pengecualian tersebut terutama berkenaan dengan keadaan pribadi buronan, kekhususan peradilan pidana di negara peminta dan macam kejahatan tertentu.

Negara-negara common law karena mendasarkan juriśdiksi kriminal mereka benar-benar pada prinsip teritorialitas, dan karena mereka tidak menghukum warga negara mereka sendiri, atas kejahatan yang dilakukan di luar negeri, biasanya mereka bersedia untuk mengekstradisikan warga negara mereka, sedangkan negara-negara civil law biasanya dicegah mengekstradisikan warga negaranya oleh undang-undang mereka. Oleh karena itu, perjanjian ekstradisi, apabila tidak dikecualikan secara keseluruhan ekstradisi warga negaranya, biasanya memberikan hak kepada negara yang diminta untuk tidak mengekstradisikan warga negaranyà, apabila hukum nasionalnya menentukan demikian. Dengan alasan ini beberapa perjanjian ekstradisi membatasi kebebasan negara yang diminta ekstradisi untuk menetralkan buronan, setelah dilakukan permintaan untuk itu. Perjanjian-perjanjian ekstradisi yang lain mewajibkan negara yang diminta ekstradisi untuk melaksanakan pengadilan kriminalitas sendiri.

Hampir semua perjanjian ekstradisi dan undang-undang nasional menentukan bahwa penyerahan tidak dapat dikabulkan, apabila kejahatan yang diminta diekstradisikan dapat dikenakan hukuman mati berdasarkan hukum 
negara peminta, keçuali penguasa negara peminta sebelumnya sudah meyakinkan bahwa hukuman mati tidak akan dikenakan atau tidak dilaksanakan. Beberapa norma memberikan kemungkinan ditolaknya ekstradisi dalam kasus-kasus yang melibatkan: hukuman yang merusak integritas fisik tersangka, hukuman yang tidak manusiawi atau yang menghinakan atau bahkan hukuman seumur hidup.

Hukum nasional dan perjanjian-perjanjian ekstradisi yang sekarang, tidak mengabulkan ekstradisi kalau ada alásản untuk meyakini bahwa pengadilan pidana di negara peminta sudah tidak sesuai atau akan tidak sesuai dengan standar minimum yang diakui secara internasional untuk jaminan prosedural. Permintaan ekstradisi dapat ditolak, apabila buronan akan diadili oleh pengadilan ad hoc, atau pengadilan luar biasa atau apabila dia telah dikenakan hukuman secara in absentia; dengan tanpa memiliki hak untuk memperoleh pengadilan ulängan, yang menjamin adanya hak untuk mempertahankan (pembelaan). Sejumlah negara menolak permintaan ekstradisi atas alasan-alasan kemanusiaan, apabila penyerahan sangat mungkin mempunyai akibat penderitaan yang khusus atạu penderitaan yang tidak proporsional bagi buronan, terutama atas alasan umur, keadaan kesehatan atau keadaan-keadaan pribadi yang lain. Kejahatan yang tidak dapat diekstradisikan:

1. kejahatan militer murni yang tidak melibatkan kejahatan biasa apapun;

2. kejahatan fiskal, misalnya penghindaran pajak, pelanggaran terhadap pengaturan tentang mata uang dan pabean (akan tetapi perjanjian dan undang-undang nasional tentang ekstradisi. yang baru, tidak lagi mengecualikan kejahatan fiskal untuk diekstradisikan);

3. kejahatan politik dengan alasan peduli. kemanusiaan pada si tersangka, dan keengganan negara terlibat dalam persoalan-persoalan politik negara tain.

4. kejahatan rasial, kejahatan diskriminatif (ini sebenarnya tidak berbeda dengan kejahatan politik).

Persidangan ekstradisi diadakan hanya atas permintaan resmi. Biasanya permintaan disampaikan melalui saluran diplomatik, dan didukung dengan dokumen-dokumen yang ditetapkan perjanjian ekstradisi yang dapat diterapkan atau kalau tidak ada, yang ditentukan oleh undang-undang ekstradisi negara yang diminta. Dokumen-dokumen yang tidak mencukupi boleh dilengkapi dalam suatu batas waktu yang ditentukan. Kebanyakan perjanjian internasional atau undang-undang ekstradisi mengatur kemungkinan, untuk suatu jangka waktu yang terbatas, dengan mendasarkan pada penerimaan suatu permintaan resmi, penahanan sementara seorang buronan, dengan cara komunikasi yang cepat, atau atas dasar surat perintah penahanan internasional, yang dikeluarkan oleh INTERPOL. Prosedur ekstradisi itu sendiri biasanya tidak merupakan materi pokok perjanjian ekstradisi, tetapi seluruhnya diserahkan pada negara yang diminta, termasuk pertanyaan sämpai dan pada tahap mana perlindungan proses peradilan tersedia bagi seorang buronan. Biasanya negara peminta tidak mempunyai peran dalam semua proses peradilan ini

Kebanyakan undang-undang ekstradisi yang mengatur prosedur ekstradisi menyediakan pengembalian dengan ijin (persetujuan), dalam hal bila buronan, yang diperintahkan dengan semestinya, menanggalkan 
peradilan formal, baik tertulis maupun di depan pengadilan atau hakim komisi. Apabila demikian, buronan dalam berbagai negara juga kehilangan perlindungan, menurut aturan spesialitas. Di negara-negara yang lain, aturan spesialitas boleh dilepaskan secara terpisah. Pelepasan yang dinyatakan secara sah biasanya tidak dapat dicabut.

Biaya-biaya untuk proses pengembalian di negara yang diminta di bebankan pada negara tersebut. Beberapa perjanjian ekstradisi mengatur bahwa biaya khusus, seperti transpor udara, dibebankan padà negara peminta. Seorang buronan yang sedang menghadapi keputusan atau peradilan pidana di negara yang diminta ekstradisi, boleh diserahkan secara sementara, apabila negara peminta akan mengembalikan buronan yang bersangkutan, sesudah selesainya pengadilan. Negara boleh bersepakat sendiri untuk mengembalikan warga negaranya sendiri, apabila mereka sudah diserahkan sementara.

Seorang buronan yang sudah diserahkan kepada negara peminta, tanpa persetujuan negara yang diminta tidak boleh diserahkan (diekstradisikan) ke negara ketiga, kecuali dia belum meninggalkan negara peminta, sesudah dia dibebaskan, untuk suatu jangka waktu yang ditentukan. Transit seorang buron dari negara yang diminta ke negara peminta, melewati wilayah negara ketiga, tergantung pada ijin (persetujuan) negara ketiga. ljin biasanya diberikan atas dasar penyampaian suatu salinan keputusan yang mengabulkan permintaan ekstradisi.

Ada kalanya ekstradiși diminta oleh dua negara atau lebih. Apabila permintaan tersebut untuk kejahatan yang sama, negara yang diminta akan' memberikan kepada negara peminta, tempat kejahatan dilakukan. Apabila permintaan ditujukan untuk kejahatan yang berbeda, maka negara yang diminta harus memutuskan sendiri, dengan mempertimbangkan beratnya kejahatan, nasionalitas buronan, tanggal masing-masing permintaan dan kemuingkinan dilakukan ekstradisi berikutnya ke negara lain. ${ }^{23}$

\section{Pemberantasan Kejahatan Ekonomi antar Negara dengan Perjanjian Ekstradisi (Perspektif Indonesia)}

Untuk mengungkap manfaat dan mendeskripsikan liku-liku perjanjian ekstradisi sebagai instrumen untuk memberantas kejahatan ekonomi antarnegara perlu digunakan sebagai pedoman unsur-unsur pokok ekstradisi. Unsur-unsur tersebut antara lain:

1. landasan ekstradisi;

2. kejahatan yang diekstradisikan;

3. orang yang diekstradisikan;

4. prosedur ekstradisi;

5. tujuan ekstradisi.

Titik awal proses ekstradisi terletak pada ada tidaknya dasar hukum untuk melakukan ekstradisi. Peluang pengkabulan permintaan ekstradisi cukup besar, apabila antara negara peminta dan yang diminta ekstradisi sudah ada perjanjian ekstradisi. Kepastian hukum untuk dapat dilakukan proses ekstradisi kapanpun juga sudah mantap. Tercapainya kesepakatan untuk menandatangani suatu perjanjian bilateral merupakan salah satu indikator hubungan diplomatik yang baik.

${ }^{23}$ Rudolf L Bindschedler. et.al. 1985. Encyclopedia of Public Intermational Law. Vol. 8. HIm. 224 -228. 
Bertolak pada bagian ini harapan terealisasinya ekstradisi Hendra Rahardja yang sekarang sedang dalam proses pengadilan nasional di Australia cukup besar. Pemerintah Indonesia dan Australia sudah bersepakat untuk menandatangani perjanjian ekstrádisi pada tanggal 22 April 1992. Kasus ini masih harus melewati kendala-kendala yang cukup banyak. Penyelesaian proses pengadilan menurut hukum nasional negara bagian Australia (New South Wales) cukup memerlukan waktu. Peran kerja sama dalam proses pengadilan menurut hukum nasionat Indonesia dan negara bagian New South Wales cukup menentukan. Kalau proses awal pengadilan Hendra Rahardja di Indonesia belum dapat dilaksanakan dengan baik, proses ekstradisi sangat berpeluang untuk terganggu.

Keadaan demikian masih ditambah lagi dengan memburuknya hubungan diplomatik antara Indonesia dan Australia pasca jajak pendapat tentang Timor Timur. Kasus pengadilan Hendra Rahardja menjadi tenggelam. Permasalahan lain yang masih mungkin juga muncul yakni pemberlakuan perjanjian ekstradisi yang dibuat oleh pemerintah federal Australia pada negara-negara bagian. Di negara bagian, tempat Hendra Rahardja diadili, (New South Wales) masih harus dilakukan proses pemberlakuan perjanjian ekstradisi tersebut, melalui prosedur amandemen. Apabila negara bagian tidak mau memberlakukan perjanjian tersebut, maka proses ekstradisi akan kandas.

Sebaliknya dimungkinkan proses ekstradisi dapat berlangsung mulus dalam keadaan tidak ada perjanjian ekstradisi, misal dalam kasus ekstradisi Zarima. Indonesia dan Amerika Serikat tidak punya perjanjian ekstradisi. Dasar hukum ekstradisi adalah resiprositas, dalam arti Amerika Serikat bersedia mengekstradisikan Zarima, kalau Indonesia juga akan mau mengekstradisikan warga negara Amerika Serikat yang melakukan kejahatan seperti Zarima yang melarikan diri atau berada di Indonesia, apabila hal itu terjadi kemudian hari.

Ada beberapa faktor yang menyebabkan kemulusan ekstradisi Zarima. Hubungan diplomatik antara Indonesia dan Amerika Serikat ketika itu cukup baik. Andaikan kasus itu terjadi sekarang, proses ekstradisi tersebut mungkin terhambat. Status Zarima di Indonesia sudah sebagai tahanan resmi, dan Zarima adalah warga negara Indonesia. Di samping itu kejahatan yang dilakukan dapat dikategorikan sebagai kejahatan internasional, yaitu - pengedaran narkotika.

Perlu dicatat bahwa dari sisi lain kasus Zarima ini dapat merupakan rendisi atas dasar resiprositas. Dalam hal ini Amerika Serikat mengembalikan seorang pelaku kejahatan (Zarima) ke Indonesia, untuk diadili oleh Indonesia atas dasar resiprositas..

Berkaitan dengan perjanjian ekstradisi perlu diingat bahwa untuk mewujdukannya harus melalui proses yang cukup lama. Sampai sekarang perjanjian ekstradisi antara Indonesia dan Singapura belum terwujud, masih ada kendala yang harus diatasi. Agar dapat memenuhi kriteria bahwa kejahatan dapat dihukum menurut hukum kedua negara harus ada kesamaan visi. Dalam hal ini Singapura menganut sistem hukum Anglo Saxon, sedang Indonesia menganut sistem hukum kontinental. Ada beberapa kejahatan yang menurut Singapura menguntungkan, sedang bagi Indonesia merugikan, seperti: pelarian modal ke luar negeri dan pencucian uang. Kalau kejahatan ini dapat diekstradisikan banyak kemungkinan merugikan Singapura. 
Demikian juga berkenaan dengan perjanjian ekstràdisi antara Indonesia dan Cina. Sistem hukum indonesia dan Cina tidak sama. Indonesia dan Cina masih harus menyelesaikan masalah kewarganegaraan rangkap. Di samping itu kebijakan pemerintah Indonesia dan Cina mengenai warga negara asing (Cina) yang ada di Indonesia, dan warga negara Indonesia keturunan Cina juga berbeda.

Mengenai kejahatan yang dapat diekstradisikan dianut tolok ukur bahwa kejahatan itu dapat dihukum menurut hukum. kedua negara, dengan pembatasan beratnya hukuman, misal hukuman penjara minimal satu tahun atau lebih berat. Sebagai conoth menurut ketentuan Pasal 2 Perjanjian Ekstradisi antara Indonesia dan Australia, 22 April 1992, kejahatan ekonomi yang dapat diekstradisikan antara lain:

1. kejahatan terhadap hukum mengenai penyuapan;

2. kejahatan yang berhubungan dengan pemalsuan uang dan surat-surat berharga;

3. kejahatan terhadap hukum mengenai pajak, bea cukai, pengawasan devisa, atau mengenai pendapatan negara lainnya;

4. mendapatkan barang atau uang, surat berharga atau kredit melalui upaya palsu atau cara penipuan lainnya;

5. kejahatan terhadap hukum mengenai kepailitan atau keadaan pailit;

6. kejahatan terhadap hukum mengenai perusahaan-perusahaan;

Menurut Pasal II Perjanjian Ekstradisi antara Indonesia dan Filipina, 10-2-1976, kejahatan ekonomi yang dapat diekstradisikan antara lain:
1. penyuapan, korupsi;

2. pemalsuan : dokumen, barang atau uang;

3. penyelundupan.

Menurut lampiran Perjanjian Ekstradisi antara Indonesia dan Thailand, 29-6-1976, kejahatan ekonomi yang dapat diekstradisikan antara lain:

1. pemalsuan dan kejahatan yang bersangkutan dengan pemalsuan;

2. penipuan dan perbuatan curang;

3. penyuapan dan korupsi;

4. penyelundupan.

Menurut lampiran Perjanjian Ekstradisi antara Indonesia dan Malaysia, 7-6-1974, kejahatan yang dapat diekstradisikan antara lain:

1. pemalsuan dan tindak pidana yang bersangkutan dengan pemalsuan;

2. penipuan;

3. perbuatan curang;

4. penyuapan dan korupsi;

5. penyelundupan.

Menurut lampiran Undang-Undang Republik Indonesia Nomor 1 Tahun 1979, tentang Ekstradisi, kejahatan ekonomi yang dapat diekstradisikan antara lain:

1. pemalsuan dan kejahatan yang bersangkutan dengan pemalsuan;

2. penipuan;

3. tindak pidana-tindak pidana yang berhubungan dengan kebangkrutan;

4. penyelundupan;

5. tindak pidana korupsi.

Kejahatan yang tegas-tegas tercakup baru: penyelundupan, kejahatan di bidang perbankan, kejahatan di bidang perniagaan, 
dan kecurangan di bidang kepabeanan. Kejahatan yang belum tercakup: kejahatan yang berkenaan dengan hukum lingkungan, kejahatan di bidang HaKI dan kejahatan komputer.

Kejahatan-kejahatan yang belum tercakup ini perlu dituangkan dalam suatu instrumen tambahan perjanjlan ekstradisi yang bersangkutan, walau memang sudah disediakan klausula untuk persoalan ini. Kalau belum secara resmi tercantum, sangat berpeluang untuk menghambat proses ekstradisi kejahatan tersebut.

Kejahatan ekonomi antar negara yang sekarang dominan merupakan kejahatan kerah putih (white colour crime). Sedangkan kejahatan kerah putih merupakan kejahatan yang terorganisasi dengan baik dan juga merupakan kejahatan sindikat. Kalau terjadi kejahatan, untuk menjaring pelakunya sangat sulit. Dalam menetapkan dia sebagai buronan tersangka, apalagi terpidana banyak kendalanya. Guna melakukan penyidikan di tingkat hukum nasional sangat sulit, perlu kerja keras dan komitmen yang tinggi. Kalau di tingkat hukum nasional tidak terjaring, proses ekstradisi tidak mungkin. Kejahatan ekonomi tersebut dapat dilakukan oleh korporasi, sehingga merupakan kejahatan korporasi. Sampai saat ini masih jarang korporasi yang dapat terjerat pidana. Lebih-lebih kalau yang melakukan adalah korporasi raksasa.

Kendala yang dihadapi dalam mengungkap kejahatan korporasi cukup banyak. Pengalaman dan pendidikan para kriminolog dalam hal kejahatan korporasi tidak memadai. Data, baik dari korporasi yang bersangkutan maupun dari lembaga yang terlibat dalam pengawasan masalah kejahatan korporasi sulit diperoleh. Biasanya pelaku kejahatan korporasi adalah orang terpandang dalam masyarakat, dihormati dan berkuasa. ${ }^{24}$ Kalau kejahatan korporasi dapat lolos dari jaring hukum nasional, maka proses ekstradisi sulit dilakukan.

Kejahatan ekonomi mungkin dapat dijadikan sebagai sistem penyelenggaraan suatu pemerintahan. Apabila hal ini terjadi sangat sulit untuk mengungkap kejahatan tersebut, sehingga ekstradisi tidak mungkin terjadi. Karenanya diperlukan kemauan politik suatu rejim untuk menjaringnya, sehingga proses ekstradisi dapat dilakukan.

Berkenaan dengan orang yang diekstradisikan, permasalahan berakar pada statusnya menuntut hukum nasional maupun hukum internasional, serta kewarganegaraannya. Untuk dapat di ekstradisikan orang yang bersangkutan harus sudah berstatus sebagai tersangka atau terpidana buron. Sebelum proses ekstradisi dapat dimulai harus dilakukan proses menurut hukum nasional sehingga dapat terbukti bahwa orang yang diekstradisi benar-benar sebagai tersangka atau terpidana. Apabila proses ini belum terpenuhi ekstradissi belum dapat dimulai. Proses ekstradisi Zarima, atau Hendra Rahardja dapat dimulai karena, status mereka adalah tersangka buron.

Terhadap buronan tersangka atau terpidana dapat diekstradisikan apabila mereka bukan orang yang dilindungi secara internasional. Misal pengadilan Augusto Pinochet di Inggris lebih banyak tersita pada penentuan dimiliki tidaknya kekebalan diplomatik oleh Pinochet.

24J.E. Sahetapy. 1994. Kejahatan Korporasi. Bandung: Penerbit P.T. Eresco. HIm. 17, 24. 
-Kalau Pinochet seperti yang diinginkan oleh Pemerintah Cile memiliki kekebalan, dia kebal terhadap hukum Inggris, sehingga tidak dapat diekstradisikan ke Spanyol. Setelah melewati proses pengadilan yang cukup panjang, akhimya keputusan pengadilan Inggris menyatakan Pinochet tidak memiliki kekebalan sehingga dia dapat diekstradisikan ke Spanyol.

Dari fokus pandang ini Hendra Rahardja dapat diekstradisikan. Dia tidak termasuk orang yang dilindungi secara internasional. Australia dapat mengekstradișikan dịa.

Kewarganegaraan orang yang diesktradisikan juga menentukan keberhasilan ekstradisi. Ekstradisi Hendra Rahardja akan dapat berjalan baik, karena dia adalah warga negara dari negara peminta, yaitu Indonesia. Ekstradisi Pinochet dapat dikabulkan karena Pinochet mempunyai kewarganegaraan bukan negara peminta (Spanyol) maupun negara yańg diminta (Inggris). Dàlam kasus Lockerbie permintaan ekstradisi atas kedua warga negara Libya ditolak, karena mereka memiliki kewarganegaraan dari negara yang diminta.

Andaikan Edy Tansil benar-benar berada - di Cina proses ekstradisi dapat mengalami hambatan. Antara Indonesia dan Cina masih ada persoalan tentang kewarganegaraan rangkap. Apabila Edy Tansil memiliki kewarganegaraan rangkap, akan terbuka peluang ekstradisi ditolak. Cina boleh menolak permintaan ekstradisi atas warga negaranya; meski dia harus mengadilinya sendiri.

Pada umumnya dalam proses ekstradisi, orang yang diesktradisikan berusaha menolak ekstradisi. Pinochet di dukung oleh pemerintah Cile berusaha keras menolak ekstradisi. Hendra Rahardja juga menolak ekstradisi. Keberhasilan ekstradisi sangat tergantung pada keberhasilan proses pengadilan nasional negara yang diminta.

Prosedur ekstradisi di bedakan menjadi prosedur dalam hukum nasional masingmasing negara peminta dan negara yang diminta dan prosedur dalam hukum internasional. Menurut hukum internasional semua tahapan dilakukan melalui saluran diplomatik. Permintaan ekstradisi beserta syarat-syarat yang dibutuhkan di sampaikan melalui saluran diplomatik. Demikian juga penyampaian jawaban pengabulan maupun ditolaknya ekstradisi dilakukan melalui saluran diplomatik. Keberhasilan ekstradisi sangat dipengaruhi oleh baik buruknya hubungan diplomatik antar negara yang terlibat.

Dalam proses hukum nasional diperlukan keseriusan masing-masing negara yang terlibat, sehingga proses peradilan dapat berjalan cepat. Disamping itu kerja sama antar negara, dalam saling memberikan dukungan, maupun alat-alat bukti ikut menentukan kebertiasilan proses ekstradisi. Dalam kasus Hendra Rahardja dokumen-dokumen maupun alat-alat bukti lain yang diberikan Indonesia ikut menentukan kelancaran dan keakuratan pengadilan Hendra Rahardja di negara bagian New South Wales. Demikian juga sikap Australia yang mau menunda sidang pertama sesuai dengan habisnya jangka waktu penyampaian permintaan ekstradisi, ikut menentukan keberhasilan ekstradisi Hendra Rahardja. Andaikan Australia tidak menunda, maka proses ekstradisi sudah tertutup, karena ketika sidang dimulai, surat permintaan ekstradisi belum ada atau belum sampai di Australia. Baik buruknya kerja sama antara negara peminta dan yang diminta sangat menentukan kelancaran proses ekstradisi. 
Keberhasilan ekstradisi juga ditentukan oleh kerjasama yang baik antara nëgara yang terlibat dan.INTERPOL. Cepatnya penangkapan Hendra Rahardja adalah hasil kerja sama yang baik dengan INTERPOL. Andaikan kerja sama jelek, kemungkinan Hendra Rahardja masih bebas mondar-mandir mengelola bișnisnya.

Ekstradisi merupakan sarana untuk dapat mengadili dan menghukum si pelaku kejahatan oleh negara tempat dilakukan kejahatan, atau negara yang memiliki jurisdiksi atas kejahatan yang bersangkutan. Dengan ekstradisi pelaku kejahatan tidak luput dari penghukuman. Melalui ekstradisi masyarakat internasional telah bekerja sama dalam mencegah dan memberantas kejahatan.

Tujuan ekstradisi yang cukup ideal tersebut akan tercapai apabila didukung oleh ketersediaan unsur-unsur pokok ekstradisi. Tersedianya jaringan perjanjian ekstradisi yang cukup memadai akan mempersempit ruang gerak pelaku kejahatan. Langkahlangkah pro aktif negara peminta maupun negara yang diminta, akan mempercepat prosedur ekstradiși, sehingga mengurangi peluang pelaku kejahatan untuk lolos dari hukuman.

\section{Simpulan}

Perjanjian Ekstradisi merupakan instrumen yang sangat membantu untuk memberantas kejahatan ekonomi antar negara. Akan tetapi kemujaraban perjanjian ekstradiși sangat ditentukan oleh beberapa faktor. Antar negara yang mempunyai hubungan ekonomi cukup besar perlu memiliki kesamaan visi dan misi, sehingga tidak mengutamakan kepentingan diri mereka masing-masing. Harmonisasi sistem hukum antar negara-negara yang terkait, seirta ketangguhan sistem péradilan mereka sangat mendukung efektivitas perjanjian ekstradisi. Kemauan politik dan kesungguhan masing-masing negara untuk memberantas kejahatan ekonomi antar negara benar-benar mendukung terjadinya proses êkstradisi.

Di samping itu jalinan hubungan diplomatik yang erat dan dekat merupakan fasilitas yang memudahkan proses ekstradisi. Hubungan jaringan INTERPOL yang cukup rapi menjadi pagar pengaman yang kuat, sehingga pelaku kejahatan kehilangan ruang gerak untuk melarikan atau menyembunyikan diri. 'o

\section{Daftar Pustaka}

Budiarto, M. 1981. Ekstradisi dalam Hukum Nasional. Jakarta: Ghalia Indonesia.

Reksodiputro, Mardjono. "Tindak Pidana Korporasi dan Pertanggungjawabannya." Pidato Dies Natalis Ke. 47. PTIK Mabes Polri. Jakarta. 1993.

J.E. Sahetapy. Kejahatan Korporasi. Penerbit P.T. Eresco, Bandung, 1994.

Tsani, Mohd. Burhan. 1990. Hukum dan Hubungan Internasional. Yogyakarta: Liberty.

Wayan, I Parthiana. 1990. Ekstradisi dalam Hukum Internasional dan Hukum Nasional Indonesia. Bandung Mandar Maju.

Hamzah. Course - Materials Penataran Nasional Hukum Pidana dan Kriminologi. di Universitas Diponegoro. Semarang, 23-31 Nopember 1998. 
Bindschedler, Rudolf L. et.al. 1985. Encyclo- Harian Suara Pẹmbaruan: Tanggal 2 Januari pedia of Public International Law. Vol. 8. Amsterdam.

Harian Suara Pembaharuan. Tanggal 19 April 1999:

Harian Suara Pembaharuan. Tanggal eo April 1999.

Harian Republika. Tanggal 31 Desember 1998.

Harian Suara Pembaruan. Tanggal 9 Maret 1999. Tanggal 4 Juni 1999.

Harian Republika. Tanggal 11,12 Juni. 1998. 